\title{
Smoking behaviour after enforcement of a $100 \%$ tax on tobacco products in Saudi Arabia: a cross-sectional study
}

Abdulrahman Alghamdi, ${ }^{1}$ Anas Fallatah, ${ }^{2}$ Fahad Okal, ${ }^{1}$ Taher Felemban, ${ }^{1}$ Mohamed Eldigire ${ }^{3}$ and Hind Almodaimegh ${ }^{4}$

${ }^{1}$ King Abdullah International Medical Research Center, King Saud bin Abdulaziz University for Health Sciences, College of Medicine, Jeddah, Saudi Arabia. ${ }^{2}$ King Abdullah International Medical Research Center, King Abdulaziz University, College of Medicine, Jeddah, Saudi Arabia. ${ }^{3}$ King Abdullah International Medical Research Center, King Saud bin Abdulaziz University for Health Sciences, College of Science and Health Professions, Department of Basic Sciences, Jeddah, Saudi Arabia. ${ }^{4}$ King Abdullah International Medical Research Center, King Saud bin Abdulaziz University for Health Sciences, College of Pharmacy, Department of Clinical Pharmacy, King Abdulaziz Medical City - NGHA, Riyadh, Saudi Arabia. (Correspondence to: Abdulrahman Alghamdi: Abdurrahman.essa@gmail.com).

\begin{abstract}
Background: Raising the prices of cigarettes is a common intervention to control tobacco use. In June 2017, Saudi Arabia imposed a 100\% excise tax on tobacco products and energy drinks.

Aims: This study aimed to evaluate the impact of the increase in prices on tobacco products and the resulting cigarette smoking behaviour in Jeddah, Saudi Arabia before and after the increase in tobacco product prices.

Methods: This cross-sectional study was conducted between December 2017 and March 2018 in Saudi Arabian smokers aged 18 years and more. A validated questionnaire was distributed to a convenience sample in public places and through Twitter. The McNemar matched pairs chi-squared test was used to evaluate the self-reported difference in cigarette smoking before and after the tax came into effect. Binary logistic regression analysis was done to identify the socioeconomic and health factors associated with stopping smoking.
\end{abstract}

Results: In all, 376 participants (80.0\% men) completed the questionnaire. A large proportion of the participants (39.6\%) reported no change in their smoking behaviour after the tax was imposed, whereas $29.8 \%$ switched to cheaper brands. Before the tax, 154 participants smoked 15 cigarettes or more a day; this figure decreased to 134 after the tax (McNemar test, $\mathrm{P}<0.001$ ). Respondents who were married, unemployed, had a higher income or who rated their health as fair were significantly more likely to have stopped smoking after the tax.

Conclusion: The sharp increase in cigarette prices in Saudi Arabia has led to a statistically significant reduction in smoking. Future research should assess the long-term effects of this intervention on smoking onset, prevalence and relapse.

Keywords: tobacco smoking, smoking cessation, taxation, Saudi Arabia

Citation: Alghamdi A; Fallatah A; Okal F; Felemban T; Eldigire M; Almodaimegh H. Smoking behaviour after enforcement of a 100\% tax on tobacco products in Saudi Arabia: a cross-sectional study. East Mediterr Health J. 2020;26(1):39-46. https://doi.org/10.26719/2020.26.1.39

Received: 12/01/19; accepted: 19/08/19

Copyright (C) World Health Organization (WHO) 2020. Open Access. Some rights reserved. This work is available under the CC BY-NC-SA 3.0 IGO license (https://creativecommons.org/licenses/by-nc-sa/3.o/igo).

\section{Introduction}

Smoking tobacco products is one of the biggest global threats to health. It is a major cause of death as it contributes to many types of cancers and other diseases that affect various body systems including the cardiovascular, pulmonary, skeletal, endocrine, digestive and reproductive systems (1). The length of exposure to tobacco products determines how rapidly these diseases develop and how severe they become (2).

About one billion people in the world are estimated to smoke tobacco products (3). In 2013, a nationally representative study was conducted to assess tobacco consumption in Saudi Arabia, which included 10735 males and females aged 15 years or older (4). The study showed that about $16.0 \%$ of Saudi Arabians had smoked tobacco in their lifetime and $12.2 \%$ were current smokers. Furthermore, among current smokers, $74.1 \%$ smoked an average of 15.1 cigarettes a day. In addition, $1.4 \%$ smoked both cigarettes and the waterpipe on a daily basis (4).

Many interventions have been implemented throughout the world to eliminate smoking. A common intervention to control smoking is to raise the price of tobacco products. A study in the United States of America on the effect of taxes and smoking bans in bars and restaurants on daily and non-daily smoking between 2001 and 2011 suggested that these measures were associated with a reduction in smoking, especially when they were combined (5). Furthermore, taxation had a stronger inverse association with daily smoking than with nondaily smoking (5). A study in men in Japan on smoking cessation attempts after an increase in the tobacco tax found that this increase was a strong motivator for trying to stop smoking in those with medium nicotine dependence according to the Fagerström test for cigarette dependence (a scores of $4-6$ ), odds ratio $(\mathrm{OR})=1.44,95 \%$ confidence interval (CI): 1.09-1.90 (6).

In Saudi Arabia, the deaths of 71 men and 21 women 
were attributed to tobacco consumption every week in 2013 (7). Smoking is also an economic burden for Saudi Arabia. Between 2001 and 2010, tobacco consumption was estimated to cost the country about US\$20.5 billion because of the cost of premature deaths and the direct and indirect costs of morbidity (8). According to the latest available data, tobacco control programmes cost the government US\$ 4.8 million a year (9). The government of Saudi Arabia has implemented many measures over the years to reduce smoking in the population. For example, a national tobacco control programme was established in 2002 by the Ministry of Health (10). This programme aims to combat smoking in the different groups of the population by providing scientific (research and evidence gathering) and advisory services. Moreover, the programme supervises more than 70 clinics across the country that help people who want to give up smoking (11). The programme also plays an important role in developing new measures to control the use of tobacco products (11).

In June 2017, Saudi Arabia imposed a $100 \%$ tax on tobacco products (including cigarettes and waterpipe tobacco) and energy drinks (12). An opinion survey by one of the most popular Arab news websites (Sabq.org), showed that $45 \%$ of the participants thought the tax would discourage smoking to a limited extent, while $61 \%$ of those who reported smoking 10-20 cigarettes a day thought that it would not affect their smoking habits at all (13).

To the best of our knowledge, no study has investigated the effects of the 2017 tax on tobacco products on the cigarette consumption of adult smokers in Saudi Arabia. We assumed that this tax would reduce cigarette smoking in the country. We therefore aimed to evaluate the effect of this tax on cigarette smoking behaviour in Saudi Arabians in the city of Jeddah and to identify the socioeconomic and health factors associated with stopping smoking.

\section{Methods}

This cross-sectional study was conducted between December 2017 and March 2018, 6 months after the government imposed the tax on tobacco products. The population consisted of all Saudi Arabian adults ( $\geq 18$ years old), men and women, who lived in Jeddah and had started smoking before June 2017.

A questionnaire was developed in Arabic to evaluate the cigarette smoking behaviour of smokers before and after the increase in the price of cigarettes as a result of the tax, and to identify the sociodemographic factors associated with stopping smoking. The questionnaire had two main parts. The first part asked for sociodemographic information about the participants including: city of residence, sex, age, marital status, education, general health status as perceived by the participant, employment and monthly income. The second part asked about smoking status before and after the increased price of cigarettes. The options for modifications in smoking habits after the tax were: reduced the number of cigarettes smoked a day, or switched to cheaper smoking method or cigarette brand. The second part also measured the current and previous (up to June 2017) number of cigarettes smoked a day and the frequency of smoking (daily or not) and if the participant had tried to stop smoking after the increase in prices.

To test the extent to which the study questionnaire could address the research objectives, the questions were reviewed for face validity by specialist clinicians in epidemiology and public health and medical educational staff at the College of Medicine of King Saud bin Abdualziz University for Health Sciences in Jeddah. The questions were modified accordingly and these questions were tested in a small pilot survey of 35 respondents drawn from the same population of the study. The pilot survey assessed the clarity and understandability of the questions and only minor changes to the wording of a few questions were made. To ensure the reliability of the questionnaire (the degree to which responses are consistent over time), a test and re-test method was used. We distributed the questionnaire to 35 respondents and their answers were recorded. Two weeks later, the same respondents again completed the questionnaire. The correlation coefficient between the two sets of responses was 0.875 , which indicates a high degree of correlation and consistency between the responses at the two different times. The questionnaire was distributed by hand in public places (e.g. shopping malls and the Corniche) in Jeddah by three of the coauthors. It was also distributed through a few Twitter accounts of public figures from Jeddah. Twitter was used to ensure that we reached groups not available in public places and to minimize the gap between male and female respondents because there is segregation between the sexes in Saudi Arabia in public places and Twitter can help overcome this.

Because prevalence studies of smokers in Jeddah are lacking, we assumed that the target population was 20 ooo. Using the sample size calculator from the Raosoft website (Raosoft ${ }^{\oplus}$, Inc.), with $95 \%$ confidence intervals, a $5 \%$ margin of error and a $50 \%$ presumed response distribution, the required sample size was calculated to be 377 .

\section{Data analysis}

Data management and analysis were done using the SPSS, version 23.0.0.0. Descriptive statistics were used (frequencies and percentages) for categorical variables, a chi-squared test of McNemar matched pairs was used to test significant differences in cigarette consumption before and after the increase in cigarette prices. In addition, a binary logistic regression analysis was used to identify the socioeconomic and health correlates of the decision to stop cigarette smoking after the prices were raised.

\section{Ethical considerations}

Ethical approval to conduct the study was obtained from King Abdullah International Medical Research Center, Riyadh, Saudi Arabia. 


\begin{tabular}{|c|c|}
\hline Sociodemographic characteristic & $\begin{array}{c}\text { No. (\%) } \\
(n=376)\end{array}$ \\
\hline \multicolumn{2}{|l|}{ Sex } \\
\hline Male & $301(80)$ \\
\hline Female & $75(20)$ \\
\hline \multicolumn{2}{|l|}{ Age (years) } \\
\hline $18-29$ years & $185(49.2)$ \\
\hline $30-44$ years & $121(32.2)$ \\
\hline $45-60$ years & $54(14.4)$ \\
\hline Over 60 years & $16(4.2)$ \\
\hline \multicolumn{2}{|l|}{ Marital status } \\
\hline Never married & $186(49.5)$ \\
\hline Married & $168(44.5)$ \\
\hline Widowed & $13(3.5)$ \\
\hline Divorced/separated & $9(2.5)$ \\
\hline \multicolumn{2}{|l|}{ Education } \\
\hline Primary school or less & $13(3.5)$ \\
\hline Intermediate or secondary school & $111(29.5)$ \\
\hline College & $229(60.9)$ \\
\hline Higher education & $23(6.1)$ \\
\hline \multicolumn{2}{|l|}{ Health status } \\
\hline Excellent & $306(81.4)$ \\
\hline Fair & $69(18.4)$ \\
\hline Poor & $1(0.26)$ \\
\hline \multicolumn{2}{|l|}{ Employment status } \\
\hline Student & $102(27.1)$ \\
\hline Employed & $226(60.1)$ \\
\hline Unemployed & $48(12.8)$ \\
\hline \multicolumn{2}{|l|}{ Monthly income (Saudi riyals ${ }^{a}$ ) } \\
\hline$<5000$ & $143(38)$ \\
\hline $5001-10000$ & $112(29.8)$ \\
\hline $10001-15000$ & $75(20)$ \\
\hline $15001-25000$ & $38(10.1)$ \\
\hline$>25000$ & $8(2.1)$ \\
\hline
\end{tabular}

\section{Results}

\section{Baseline characteristics}

A total of 376 adults took part in the study and completed the survey; $301(80.1 \%)$ were men (Table 1). Almost half of the respondents (49.2\%) were aged between 18 and 29 years and had never been married (49.5\%). Most of the respondents $(81.4 \%)$ described their health status as excellent. About two thirds of the respondents $(67.0 \%)$ were college graduates or had a postgraduate degree and 102 (27.1\%) were students (high school or university). Most of the respondents (60.1\%), were employed.

\section{Cigarette smoking status evaluation}

Table 2 summarizes the cigarette consumption of the male and female respondents. About $40 \%$ of the partic- ipants reported no change in their smoking behaviour after the increase in cigarette prices, whereas about 30\% switched to a cheaper cigarette brand. Of the whole sample, $174(46.3 \%)$ participants had previously tried to stop smoking before the increase in prices in 2017, while 135 $(35.9 \%)$ tried to quit in the 6 months after the price increase. A slightly greater percentage of females (48.0\%) than males $(37.5 \%)$ reported no change in their smoking behaviour after the increase in prices. In addition, fewer females than males attempted to stop smoking before the price increase (29.3\% versus $50.5 \%$ respectively) or after it (24.0\% versus $38.9 \%)$. Before the increase in cigarette prices, $167(44.4 \%)$ respondents reported that they smoked 15 cigarettes or more a day, while $113(30.1 \%)$ reported that they smoked fewer than 15 cigarettes a day. After the price increase, these figures were 138 (36.7\%) and 126 (33.5\%) respectively.

\section{Reduction in cigarette smolking}

Table 3 shows the results of the McNemar test for matched pairs of cigarette consumption which indicated a significant difference in cigarette consumption in the study population before and after the tax was imposed $\left(\chi^{2}=22.2, P\right.$ value $\left.<0.0001\right)$. As shown, before the tax was imposed, 154 of the participants smoked 15 or more cigarettes a day, and this number decreased to 134 after the tax came into force. At the same time, the number of respondents who smoked less than 15 cigarettes a day increased from 99 to 119.

\section{Factors associated with changes in smoking behaviour}

Table 4 shows the results of binary logistic regression where the dependent variable was stopping cigarette smoking in the 6 months after the tax was imposed. Sex, age, and education were not significantly associated with the decision to stop smoking after the tax was imposed. In contrast, married respondents were more likely to stop smoking after the tax (OR $=3.24,95 \% \mathrm{CI}$ : 1.15-6.97) compared with those who were never married. In addition, respondents with self-reported fair health status were more likely to stop smoking after the tax came into effect $(\mathrm{OR}=2.96,95 \% \mathrm{CI}: 1.32-5.24)$ compared with those who reported an excellent health status. Unemployed respondents were more likely to stop smoking after the $\operatorname{tax}(\mathrm{OR}=3.36,95 \% \mathrm{CI}: 1.15-9.71)$ compared with students. Compared with respondents with a monthly income of < 5000 Saudi riyals (1 US\$ $=3.75$ Saudi riyals), respondents with a monthly income of 5001-10 000 Saudi riyals and 15 001-25 000 Saudi riyals were more likely to stop smoking, $\mathrm{OR}=2.56,95 \% \mathrm{CI}: 1.26-5.23$ and $\mathrm{OR}=3.36,95 \% \mathrm{CI}$ : $1.53-8.91$ respectively.

\section{Discussion}

In June 2017, the Saudi Arabian government doubled the price of tobacco products as a means to control smoking in the country. In this study, we aimed to assess the effect of this tax on the smoking behaviour among cigarette smokers in Jeddah, Saudi Arabia. 


\begin{tabular}{|c|c|c|c|}
\hline \multirow[t]{2}{*}{ Variable } & Male & Female & Total \\
\hline & $\mathbf{N}(\%)$ & $\mathbf{N}(\%)$ & $\mathbf{N}(\%)$ \\
\hline \multicolumn{4}{|l|}{ Change in smoking behaviour after price increase of cigarettes } \\
\hline No change & $113(37.5)$ & $36(48)$ & $149(39.6)$ \\
\hline Switched to another tobacco method of smoking & $23(7.6)$ & $7(9.3)$ & $30(8)$ \\
\hline Switched cigarette brand & $93(30.9)$ & $19(25.3)$ & $112(29.8)$ \\
\hline Reduce smoking amount & $34(11.3)$ & $8(10.7)$ & $42(11.2)$ \\
\hline Reduced smoking amount and switched cigarette brand & $38(12.6)$ & $5(6.7)$ & $43(11.4)$ \\
\hline \multicolumn{4}{|l|}{ Attempted to quit before price increase } \\
\hline Yes & $152(50.5)$ & $22(29.3)$ & $174(46.3)$ \\
\hline No & $149(49.5)$ & $53(70.6)$ & $202(53.7)$ \\
\hline \multicolumn{4}{|l|}{ Attempted to quit after price increase } \\
\hline Yes & $117(38.9)$ & $18(24)$ & $135(35.9)$ \\
\hline No & $184(61.1)$ & $57(76)$ & $241(64.1)$ \\
\hline \multicolumn{4}{|l|}{ Cigarette consumption before price increase } \\
\hline Less than daily & $33(10.9)$ & $15(20)$ & $48(12.8)$ \\
\hline Daily $<15$ cigarettes & $147(48.8)$ & $20(26.7)$ & $167(44.4)$ \\
\hline Daily $\geq 15$ cigarettes & $91(30.2)$ & $22(29.3)$ & $113(30.1)$ \\
\hline Don't know & $30(9.9)$ & $18(24)$ & $48(12.8)$ \\
\hline \multicolumn{4}{|l|}{ Cigarette consumption after price increase } \\
\hline Less than daily & $46(15.3)$ & $17(22.7)$ & $63(16.8)$ \\
\hline Daily $<15$ cigarettes & $122(40.5)$ & $16(21.3)$ & $138(36.7)$ \\
\hline Daily $\geq 15$ cigarettes & $101(33.6)$ & $25(33.3)$ & $126(33.5)$ \\
\hline Don't know & $32(10.6)$ & $17(22.7)$ & $49(13)$ \\
\hline
\end{tabular}

Before the 2017 tax, the Saudi Arabia government had taken many steps to control and prevent smoking. For example, in 2005, Saudi Arabia adopted the World Health Organization Framework Convention on Tobacco Control (14). By December 2016, the total taxes imposed on the most popular tobacco brand were $33.3 \%$ for cigarettes and $40 \%$ for waterpipes (9). Despite that, according to a survey conducted in 1995, prices were not a concern to smokers in Saudi Arabia (15). We found that imposing a 100\% tax on tobacco products was significantly associated with a reduction in cigarette smoking. This is consistent with the literature, where increasing cigarettes prices has been proven to be an effective intervention to reduce smoking (16-20).
Although the relationship between smoking cessation and socioeconomic factors has been studied in depth in many cultures (21-26), few studies on the factors affecting the decision to stop smoking have been conducted on Saudi Arabians. Our results showed that several factors were significantly associated with an increased willingness to stop smoking after the tax was imposed.

First, marital status was a statistically significant predictor of smoking reduction and cessation after the tax. Those who were married were three times more likely to quit smoking than those who had never married. This is consistent with another study in Saudi Arabia where being single was strongly associated with smoking (27). However, another study in male Saudi Arabian college

$\begin{aligned} & \text { Table } 3 \text { Difference in cigarette consumption before and after implementation of the tax on cigarettes: McNemar test for matched } \\
& \text { pairs }\end{aligned}$
\begin{tabular}{lcccc} 
After the tax & Before the tax \\
& $<\mathbf{1 5}$ cigarettes a day & $\mathbf{1 5}$ cigarettes a day & Total & McNemar test \\
$<15$ cigarettes a day & 90 & 29 & 119 & $\chi 2=22.2, \mathrm{OR}=3.2, \mathrm{P}<0.001$ \\
$\geq 15$ cigarettes a day & 9 & 125 & 134 & 253 \\
Total & 99 & 154 & \\
\hline
\end{tabular}

OR $=$ odds ratio. 


\begin{tabular}{|c|c|c|}
\hline Variable & P-value & OR $(95 \% \mathrm{CI})$ \\
\hline \multicolumn{3}{|l|}{ Sex } \\
\hline Male & & 1.0 (ref) \\
\hline Female & 0.617 & $0.840(0.75-1.21)$ \\
\hline \multicolumn{3}{|l|}{ Age (years) } \\
\hline $18-29$ & & 1.0 (ref) \\
\hline $30-44$ & 0.785 & $1.113(0.79-1.45)$ \\
\hline $45-60$ & 0.093 & $0.398(0.17-0.88)$ \\
\hline$\geq 60$ & 0.454 & $1.763(1.10-2.24)$ \\
\hline \multicolumn{3}{|l|}{ Marital status } \\
\hline Never married & & 1.0 (ref) \\
\hline Married & 0.003 & $3.24(1.15-6.97)$ \\
\hline Widowed & 0.026 & $5.41(1.23-23.83)$ \\
\hline Divorced/separated & 0.758 & $0.70(0.53-1.65)$ \\
\hline \multicolumn{3}{|l|}{ Education } \\
\hline Primary school or less & & 1.0 (ref) \\
\hline Intermediate or secondary school & 0.220 & $1.67(1.16-2.32)$ \\
\hline College & 0.713 & $0.85(0.64-1.37)$ \\
\hline Postgraduate & 0.836 & $1.15(0.90-1.54)$ \\
\hline \multicolumn{3}{|l|}{ Health status } \\
\hline Excellent & & 1.0 (ref) \\
\hline Fair & 0.006 & $2.96(1.32-5.24)$ \\
\hline Poor & 0.915 & $0.81(0.67-1.65)$ \\
\hline \multicolumn{3}{|l|}{ Employment status } \\
\hline Student & & 1.0 (ref) \\
\hline Employed & 0.430 & $0.73(0.46-1.49)$ \\
\hline Unemployed & 0.026 & $3.36(1.15-9.71)$ \\
\hline \multicolumn{3}{|l|}{ Monthly income (Saudi riyals) ${ }^{a}$} \\
\hline$<5000$ & & 1.0 (ref) \\
\hline $5001-10000$ & 0.010 & $2.56(1.26-5.23)$ \\
\hline $10001-15000$ & 0.131 & $0.53(0.33-1.10)$ \\
\hline $15001-25000$ & 0.027 & $3.36(1.53-8.91)$ \\
\hline$>25000$ & 0.428 & $0.43(0.26-1.01)$ \\
\hline
\end{tabular}

OR: odds ratio; $95 \%$ CI: $95 \%$ confidence interval; ref: reference category.

a1 US $\$=3.75$ Saudi riyals

Note: The dependent variable was stopping cigarette smoking in the 6 months after the implementation of the tax on cigarettes in 2017.

students reported that marital status was not a predictor of the willingness to stop smoking (28). This difference can be attributed the fact that the latter study consisted of single students, making the assessment of the effect of marital status inappropriate. Second, respondents who reported their general health status as fair were about three time more likely to stop smoking after the tax than those who considered their health to be excellent. The combined effect of these factors (marriage and suboptimal self-perceived health status) together with the financial strain caused by the tax could be the reason for the increased willingness to quit smoking.

Unemployment was also significantly associated with stopping smoking. Research in other countries has shown a high prevalence of smoking among unemployed people $(29,30)$. Price increases of tobacco products might provide this group with a valuable chance to reduce and stop smoking.

Interestingly, respondents with a higher monthly income (between 150001 and 25000 Saudi riyals) were more likely to stop smoking than individuals with a low monthly income. Other studies have shown that people with a lower income tend to be more or equally responsive to increases in cigarette prices $(31,32)$. This difference might be because switching to lower priced brands was the most common behavioural change among smokers in our sample. However, a longer follow-up of a nationally representative sample of smokers might help explore the 
long-term effects of the tax on those with lower income and explain why they were less sensitive to it in the first 6 months of its implementation.

\section{Limitations}

Our study has some limitations. First, the convenience sampling limits the generalization of results to the whole Saudi Arabian population. Second, the study sample was over-represented by educated participants and, hence, the results should be interpreted with caution. Third, our data on smoking were self-reported by the participants, which is subject to recall bias and social desirability bias - participants may not have been truthful about their smoking because of the traditional and conservative society in Saudi Arabia. Fourth, our study was limited to the city of Jeddah, Saudi Arabia. For that reason, a more comprehensive study is needed to assess the overall effect of the tax on different groups of smokers in all of Saudi Arabia

\section{Conclusion}

In summary, the sharp increase in cigarette prices in Saudi Arabia has led to a statistically significant reduction in smoking. The most common behaviour was switching to lower priced brands. Respondents who were married, unemployed, with higher income, or with fair self-reported health status were more likely to stop smoking after the tax was imposed. Future research should be directed to assessing the long-term effect of this intervention in terms of smoking onset, prevalence and relapse. Furthermore, other methods of assessing response to tobacco control interventions such as cigarette sales data and non-invasive biochemical measures (e.g. exhaled breath carbon monoxide) are more reliable ways to assess the effect of the tax on smoking behaviour.

Funding: None.

Competing interests: None declared.

\section{Comportement tabagique après l'entrée en vigueur d'une taxe de $100 \%$ sur les produits du tabac en Arabie saoudite : étude transversale \\ Résumé}

Contexte : La hausse du prix des cigarettes est une mesure couramment mise en place dans la lutte antitabac. En juin 2017, l'Arabie saoudite a imposé un droit d'accise de $100 \%$ sur les produits du tabac et les boissons énergisantes.

Objectif : La présente étude avait pour objectif d'évaluer l'impact de la hausse des prix des produits du tabac et le comportement tabagique qui en résulte à Djeddah (Arabie saoudite) avant et après cette augmentation des prix.

Méthodes : Il s'agissait d'une étude transversale qui a été menée entre décembre 2017 et mars 2018 auprès de fumeurs saoudiens de 18 ans et plus. Un questionnaire validé a été distribué à un échantillon de commodité dans les lieux publics et sur Twitter. Le test $\chi^{2}$ de McNemar pour les paires concordantes a été utilisé pour évaluer le changement de comportement en matière de tabagisme par cigarettes avant et après l'entrée en vigueur de la taxe. L'analyse de régression logistique binaire a été utilisée pour identifier les facteurs socio-économiques et sanitaires associés au sevrage tabagique.

Résultats : Au total, 376 participants ( $80 \%$ d'hommes) ont rempli le questionnaire. Une proportion importante des participants $(39,6 \%)$ n'a rapporté aucun changement dans leur comportement tabagique après l'application de la taxe, tandis que $29,8 \%$ des participants se sont tournés vers des marques moins chères. Avant l'entrée en vigueur de la taxe, 154 participants fumaient plus de 15 cigarettes par jour; ce nombre est passé à 134 suite à l'imposition de la taxe $(p<0,0001)$. Les personnes interrogées qui étaient mariées, sans emploi, avaient des revenus élevés ou s'estimaient en bonne santé étaient plus susceptibles d'avoir arrêté de fumer après l'entrée en vigueur de la taxe.

Conclusion: La hausse marquée du prix des cigarettes en Arabie saoudite a entrainé une réduction du tabagisme statistiquement significative. Les futures études devraient évaluer les effets à long terme de cette mesure sur la mise en place du tabagisme, la prévalence du tabagisme par cigarettes et les rechutes.

$$
\begin{aligned}
& \text { سلوك التدخين بعد تطبيق الضرائب بنسبة . . 1 ٪ على منتجات التبغ في المملكة العربية السعودية: دراسة شاملة لعدة قطاعات }
\end{aligned}
$$

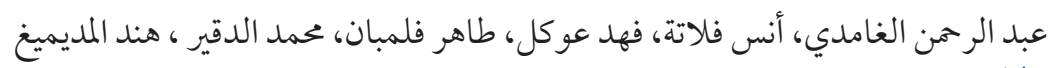

$$
\begin{aligned}
& \text { الخلاصة }
\end{aligned}
$$

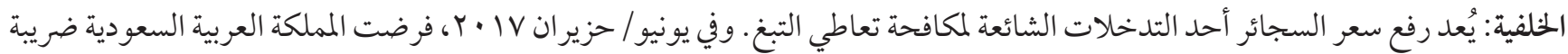

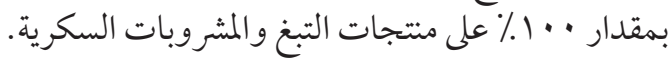

$$
\begin{aligned}
& \text { الأهداف: هدفت هذه الدراسة إلى تقييم أثثر رفع أسعار السجائر على سلوك التدخين الذي ينتهجه المدخنون السعوديون في جدة، المملكة العربية } \\
& \text { السعودية. }
\end{aligned}
$$

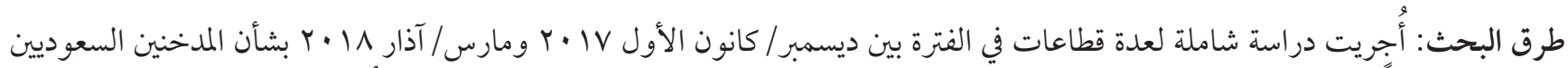

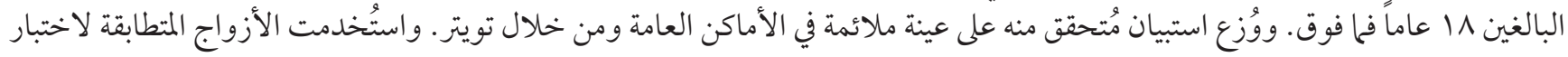




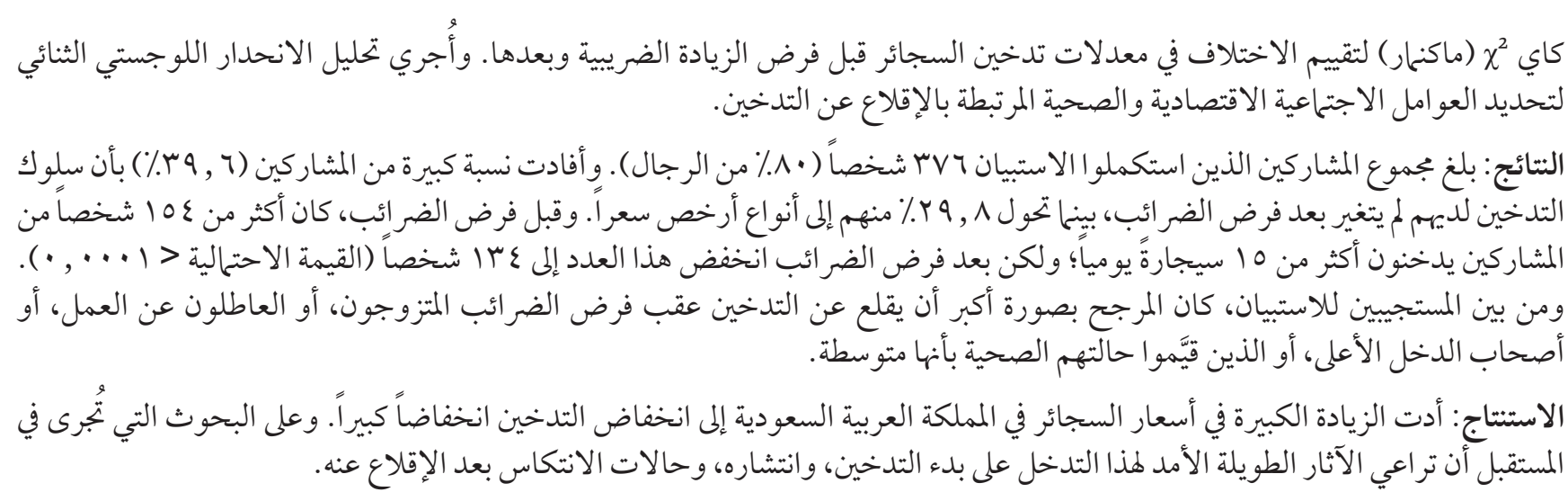

\section{References}

1. Benowitz N. Nicotine addiction. N Eng J Med 2010;362(24):2295-303 (https://doi.org/10.1056/NEJMrao809890)

2. How Tobacco Smoke Causes Disease: The Biology and Behavioral Basis for Smoking-Attributable Disease: A Report of the Surgeon General. Atlanta (GA): Centers for Disease Control and Prevention; 2010.

3. World Health Organization. Tobacco. Geneva: World Health Organization; 2017 (http://www.who.int/mediacentre/factsheets/ fs339/en/, accessed 11 Augusut 2017).

4. Moradi-Lakeh M, El Bcheraoui C, Tuffaha M, Daoud F, Al Saeedi M, Basulaiman M, et al. Tobacco consumption in the Kingdom of Saudi Arabia, 2013: findings from a national survey. BMC Public Health 2015;15(1):3-4.

5. Ballester L, Auchincloss A, Robinson L, Mayne S. Exploring impacts of taxes and hospitality bans on cigarette prices and smoking prevalence using a large dataset of cigarette prices at stores 2001-2011, USA. Int J Env Res Public Health 2017;14(3):e318.

6. Tanihara S, Momose Y. Reasons for smoking cessation attempts among Japanese male smokers vary by nicotine dependence level: a cross-sectional study after the 2010 tobacco tax increase. BMJ Open 2015;5(3): e006658.

7. Saudi Arabia [Internet]. The Tobacco Atlas. 2017 (http://www.tobaccoatlas.org/country-data/saudi-arabia/, accessed 18 August 2017)

8. AlBedah A, Khalil M. The economic costs of tobacco consumption in the Kingdom of Saudi Arabia. Tob Control 2013;23(5):434-6.

9. World Health Organization. WHO report on the global tobacco epidemic, 2017: Country profile: Saudi Arabia. Geneva: World Health Organization; 2017 (http://www.who.int/tobacco/surveillance/policy/country_profile/sau.pdf, accessed 18 August 2017).

10. Al-Munif M. Report on Tobacco Control Program of Ministry of Health. Kingdom of Saudi Arabia Ministry of Health Assisting Agency to the Preventive Medicine Tobacco Control Program. 2009:3 (http://www.sa-tcp.com/newsite/user/pdf/REPORT_ON_ TCP.pdf, accessed 9 August 2017).

11. Ministry of Health. Tobacco Control Program - Achievements. Riyadh: Ministry of Health (Saudi Arabia); 2018 (https://www. moh.gov.sa/en/Ministry/Structure/Programs/TCP/Pages/Achievements.aspx, accessed 27 August 2018).

12. Saudi Arabia to impose tax on tobacco, sugary drinks on June 10. Arab News. 29 May 2017 (http://www.arabnews.com/ node/1106726/business-economy, accessed 11 August 2017).

13. Opinion Survey on Government Taxation. Sabq.org. 2017 (https://sabq.org/material/material-attachment/5988078aa2e840d8576f996c, accessed 12 August 2017).

14. Bassiony M. Smoking in Saudi Arabia. Saudi Med J 2009;30(7):876-81.

15. Al-Faris E. Smoking habits of secondary school boys in Rural Riyadh. Public Health 1995;109(1):47-55.

16. Bader P, Boisclair D, Ferrence R. Effects of tobacco taxation and pricing on smoking behavior in high risk populations: a knowledge synthesis. Int J Environ Res Public Health 2011;8(11):4118-39.

17. Guindon G, Paraje G, Chaloupka F. The impact of prices and taxes on the use of tobacco products in Latin America and the Caribbean. Am J Public Health 2015;105(3):e9-19.

18. Kostova D, Husain M, Chaloupka F. Effect of cigarette prices on smoking initiation and cessation in China: a duration analysis. Tob Control 2016;26(5):569-74.

19. Chaloupka F, Straif K, Leon M. Effectiveness of tax and price policies in tobacco control. Tob Control 2010;20(3):235-8

20. Hill S, Amos A, Clifford D, Platt S. Impact of tobacco control interventions on socioeconomic inequalities in smoking: review of the evidence. Tob Control 2013;23(e2):e89-97.

21. Lee C, Kahende J. Factors associated with successful smoking cessation in the United States, 2000. Am J Public Health 2007;97(8):1503-9.

22. Smiley S. Sociodemographic correlates of intention to quit smoking for good among U.S. adult menthol and non-menthol smokers: Evidence from the 2013-2014 National Adult Tobacco Survey. Tob Prev Cessation 2018;4(May):22. 
23. Caponnetto P, Polosa R. Common predictors of smoking cessation in clinical practice. Respir Med 2008;102(8):1182-92.

24. West R, McEwen A, Bolling K, Owen L. Smoking cessation and smoking patterns in the general population: a 1-year follow-up. Addiction 2001;96(6):891-902.

25. Vangeli E, Stapleton J, Smit E, Borland R, West R. Predictors of attempts to stop smoking and their success in adult general population samples: a systematic review. Addiction 2011;106(12):2110-21.

26. Japuntich S, Leventhal A, Piper M, Bolt D, Roberts L, Fiore M et al. Smoker characteristics and smoking-cessation milestones. Am J Prev Med 2011;40(3):286-94.

27. Saeed A, Khoja T, Khan S. Smoking behaviour and attitudes among adult Saudi nationals in Riyadh City, Saudi Arabia. Tob Control 1996;5(3):215-19.

28. Almogbel Y, Abughosh S, Almogbel F, Alhaidar I, Sansgiry S. Predictors of smoking among male college students in Saudi Arabia. East Mediterr Health J 2013;19(11):909-14.

29. De Vogli R. Unemployment and smoking: does psychosocial stress matter? Tob Control 2005;14(6):389-95.

30. Henkel D. Unemployment and substance use: a review of the literature (1990-2010). Curr Drug Abuse Rev 2011;4(1):4-27.

31. Siahpush M, Wakefield M, Spittal M, Durkin S, Scollo M. Taxation reduces social disparities in adult smoking prevalence. Am J Prev Med 2009;36(4):285-91.

32. Farrelly M, Bray J, Pechacek T, Woollery T. Response by adults to increases in cigarette prices by sociodemographic characteristics. Southern Economic Journal 2001;68(1):156-165. 